(昭和 32 年 8 月 26 日受理)

$$
\text { パルプのエマルジョン硫化について }
$$

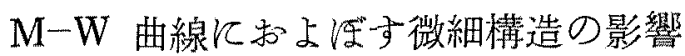

\title{
東京大学揋学部 中尾統一・大屋裕光・右田伸彥 \\ EMULSION XANTHATION OF PULP-INFLUENCE OF FINE STRUCTURE ON M-W CURVE
}

By Osakazu Nakao, Hiromitsu Ohya, and Nobuhiko Migita

(Faculty of Agriculture, Tokyo University, Tokyo, Japan)

M-W curve, obtained by varying concentrations of sodium hydroxide solution in emulsion xanthation of pulp, may be influenced by some characteristics of pulp, such as distribution of cellulose chain length, morphological and fine structure, etc. In this paper, the relation between $\mathrm{M}-\mathrm{W}$ curve and the fine structure was studied.

The curve can be characterized by its position and shape. The concentration of sodium hydroxide solution, in which half of pulp goes into solution, was adopted for expression of the position of the curve, and is symbolized with $[\bar{C}]_{p}$. To express the shape of the curve, we adopted the parameter $\left(n_{0}\right)$ obtained by the procedure, which was proposed by H. Takenaka for representaion of the distribution curves of degree of polymerization of high polymers and was modified by us. In this paper the parameter $\left(n_{0}\right)$ means mainly the slope of the curve.

The relations between the fine structure of pulp and $\left(n_{0}\right)$ and $[\bar{C}]_{0}$, are as follows;

(1) The slope $\left(n_{0}\right)$ of $M-W$ curve decreases with increasing the ununiformity of lateral order distribution and the amount of low ordered region (Fig. 9, 12).

(2) If the average lateral order level $[\bar{C}]_{\text {H }}$ becomes lower, the position of $\mathrm{M}-\mathrm{W}$ curve tends to move toward the lower sodium hydorxide concentation range, namely $[\bar{C}]_{0}$ decreases (Fig. 1). However the position of $M-W$ curve $[\bar{C}]_{0}$ is not only controlled by the average lateral order level $[\bar{C}]_{\mathrm{H}}$, but also by the distribution of lateral order, especially the relation between the specific surface area and the lateral order level of pulp.

(Received 26. 8. 1957)

\section{I. 緒言}

パルプのェマルジョン硫化 (E.X.) のときの NaOH 濃度をかえて求めた溶解曲線( $(\mathrm{M}-\mathrm{W}$ 曲楾)はパルプの 諸性皡を反映しているものと思われる。Bartunek はこ

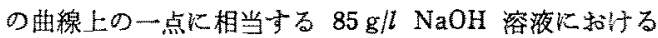

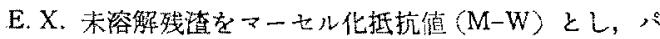
ルブの反応性の一つの目安としているき。しかし，パル プのマーをル化抵抗性は原料や製造法によつてか索り異

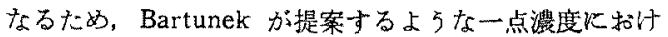
る比較はしばしば反応性の目安にならない埸合むおる。 それでわれわれはバルプの反性を检討する立場から， この曲線去のるのを解析することを試みた。

$\mathrm{M}-\mathrm{W}$ 曲楾比影䇾与るパルプの諸性質のうち，主なる

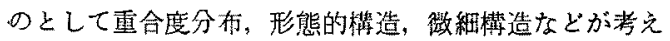

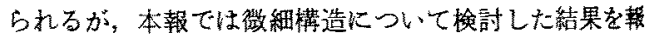
告古节。

\section{II. 䒠 驗}

研究片法として，原試料とメタノリシスした試料(M 一陚料) の同者の $\mathrm{M}-\mathrm{W}$ 曲線它比㜞与方法採つた。

1. 供 試料

市販の溶解用亚硫酸パルプ(DSP)，リンター・パルブ

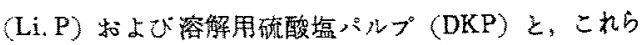
を各種濃度 $\mathrm{NaOH}(6 \sim 17.5 \%)$ 溶液に浸清したもの， ならびに卆れぞれをメタノリシスしたるのを試料に供し た。末処理バルプの分析值を Table IK示す。

\section{2. 試料の销整法}

a. 入夕ノリシス条件： $11 \mathrm{~N}-\mathrm{HCl}: \mathrm{CH}_{3} \mathrm{OH}=5: 95$ (容量) の混液をく゚ルプに対して 100 倍量加え, $84^{\circ} \mathrm{C}$ て 
Table I

\begin{tabular}{c|c|c|c|c|c}
\hline & $\begin{array}{c}\alpha-\text { Cellu- } \\
\text { lose } \\
(\%)\end{array}$ & $\begin{array}{c}\beta-C e l l u \\
\text { lose }\end{array}$ & $\begin{array}{c}\text { Pitch } \\
(\%)\end{array}$ & $\begin{array}{l}\text { Ash } \\
(\%)\end{array}$ & $\begin{array}{l}\text { Degree } \\
\text { of Poly- } \\
\text { meriza- } \\
\text { tion }\end{array}$ \\
\hline DSP & 91.7 & 4.5 & 0.08 & 0.08 & 760 \\
Li.P & 98.2 & 1.3 & 0.10 & 0.08 & 860 \\
DKP & 94.3 & 3.0 & - & - & 730 \\
\hline
\end{tabular}

メタノリシスを行つた。いわゆる平衡重合度に達するの に最も長時間かかると思われる木材パルプの場合にも， この条件では $2 \mathrm{hrs}$ で重合度約 180 に低下し, 乙の後 の低下はきわめて緩慢であつたのでメタリシスの時 間は 3 hrs とした。

なおこのよらな条件で調彆されたそれぞれの M-試料 は、形態的構造ならびに重合度分布因子の影響が消され、 主に微細構造の性質を $\mathrm{M}-\mathrm{W}$ 曲線に反映すると思われ 万。

b. アルカリ浸漬試料の調制：各韩濃度 $\mathrm{NaOH}$ 溶液 (6〜17.5\%) をパルプに対して 20 倍量加え, スラリー 状で $20^{\circ} \mathrm{C}$ て $2 \mathrm{hrs}$ 保持した後, 王搾滤過し, 同濃度 $\mathrm{NaOH}$ 溶液で洗注, ただちに桸酷酸で中和し, 濾液が中 性になるまで，水洗風乾にした。

\section{E.X. 可溶度の測定法}

緦乾重量 $0.5 \mathrm{~g}$ に相当する風乾北料に， $50 \mathrm{ml}$ の Na $\mathrm{OH}$ 溶液と $1.0 \mathrm{ml} \mathrm{CS} 2$ を加之, $25^{\circ} \mathrm{C}$ で $4 \mathrm{hrs}$ 反応さ せた。残渣の洗洛には $60 \mathrm{~g} / \mathrm{l} \mathrm{NaOH}$ 溶液を用いた2。

\section{5. 水分吸缮墨の澌定法}

$20^{\circ} \mathrm{C}, 66 \%$ 相対湿度における水分吸着量を测定した。 調湿には西硝酸ソーダ飽和溶液を用いた。なおアルカリ 浸漬陚料については，浸清後乾杪することなく，湿潤状 態から相対湿度 $66 \%$ に調湿した。

\section{III. 実 暍 結 果}

末処理 DSP，DKP，Li.P 括よびそれぞれの M-試料 について求めた M-W 曲線を Fig. 1 に示す。

$\mathrm{M}$-試料の曲線の立嘿が在（高 $\mathrm{NaOH}$ 濃度側）になる ものはど，未処理パルプの曲線の位犆も右にある。かつ 3重のパルプ共に，M-試料の曲線は未処理パルプの曲 楾より左（低 $\mathrm{NaOH}$ 浀度側）飞あつて，この差は主に形 態的構造と重合度分布因子に上るものと思われる。また $\mathrm{M}$-試料の M-W 曲線の傾斜が急であるすのほど, 朴処 理パルプの M-W 曲線の傾斜も急である。

M-試料の $\mathrm{M}-\mathrm{W}$ 曲線を微分してえられる曲線は，万 木・前田 ${ }^{3)}$ 法によるいわゆるラテラル・オーダー（L.O.） 分布曲線と同じ内容のものでかり(な括この点について は别途報告の予定)，これを Fig. 2 に示す。この图によ れば上記の関係はさらに明瞭になる。すなわらL.O. 分

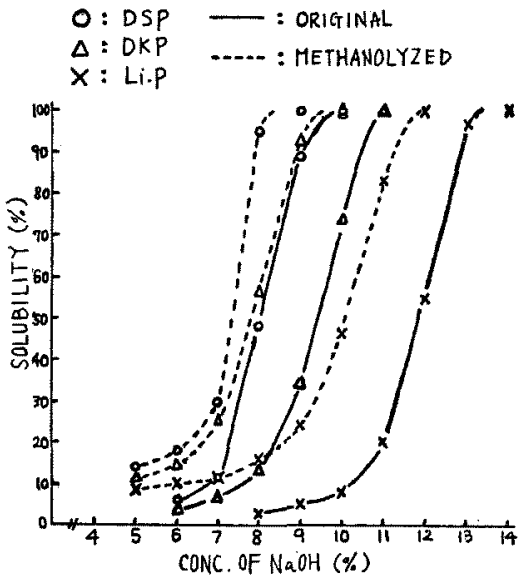

Fig. 1 Emulsion xanthation solubility curves: Solubilities at varying concentration of $\mathrm{NaOH}$ solutions with constant amount of $\mathrm{CS}_{2}$

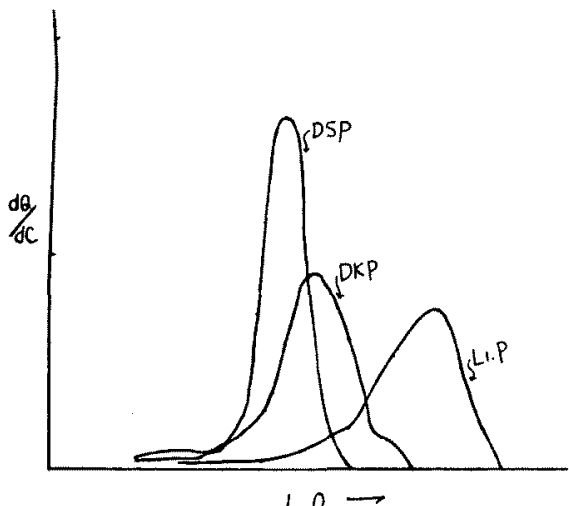

Fig. 2 Lateral order distribution curves, calculated from methanolyzed-curves at Fig. 1

布明線のピークの仙置が右にあるすのほど末処理パルプ の M-W 曲線右にあり，ピークの隔の狭いものすなわ ち分布の均一なものほど未炠理パルプの M-W 曲線の傾 斜当急である。

以上がらパルプの微細筑造が，M-W 曲線の位置や傾 斜にき如めてよく反眣していることがかかる。しかるに， マーセル化パルプの微細楧造は原パルプに比べて低オー ダ一侧に移行しているが文，M-W 曲缐は高 $\mathrm{NaOH}$ 濃度 僛《移行するらうこれはFig. 1 にみられた関係が必五し も成立しない場合があることを示す。そこで各種濃度

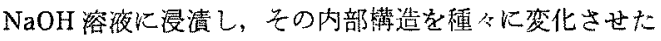
DSP, Li.P について，Fig. 1 と同㥞の曲線を求めた。 その結果を Fig. 3，4，5 および6に示す。微細櫣造の 変化(Fig. 4扣よび6)に伴なう M-W 曲線の変化 (Fig. 3 および5)は，Fig. 1 の関係と異なり，む Li.P と 


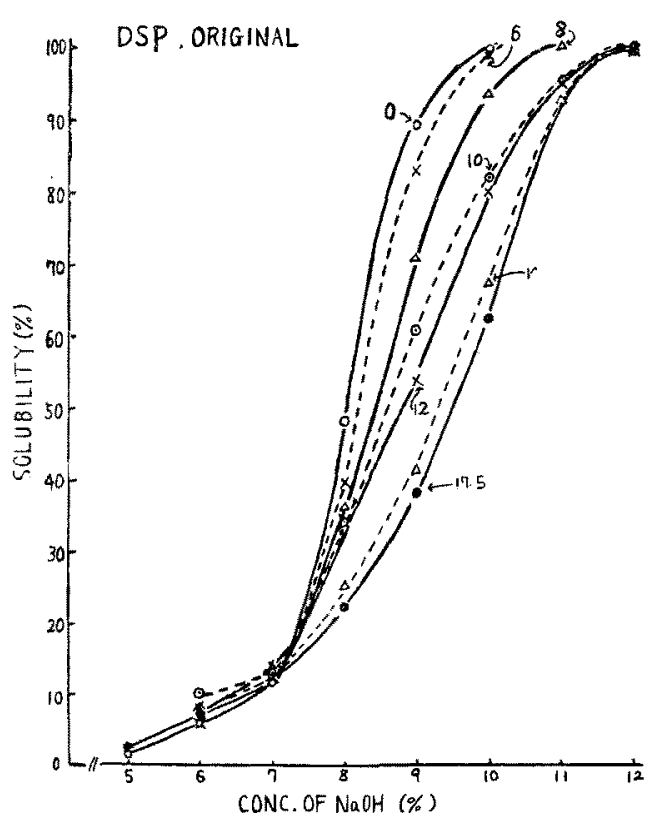

Fig. 3 Emulsion xanthation solubility curves of DSP, steeped in different concentration of $\mathrm{NaOH}$ solutions

(Figures on each curve show the concentrations of steeping $\mathrm{NaOH}$ solutions)

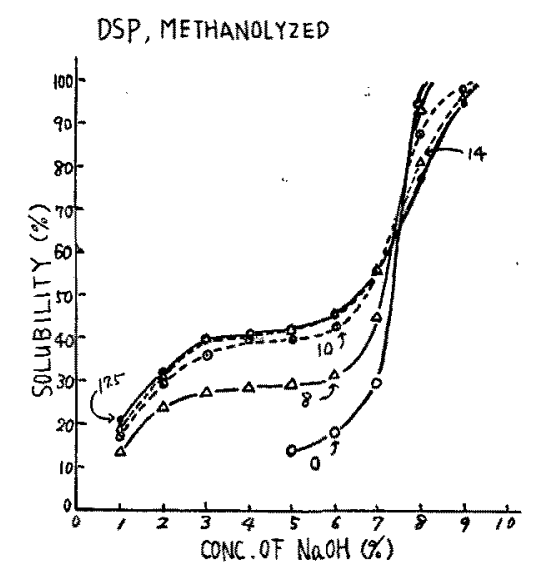

Fig. 4 Emulsion xanthation solubility curves of DSP methanolyzed after steeping in different concentrations of $\mathrm{NaOH}$ solutions

(Figures on each curve show the concentrations of steeping $\mathrm{NaOH}$ solutions)

DSP の間でもかなり異なつていることがわかる。

しかしながらこれらの曲線について，直接楮察するの は煩雑であるのでここれらの曲線を特性づけるパラメー ターを求め，このパラメーターを用いて考察を進めるこ

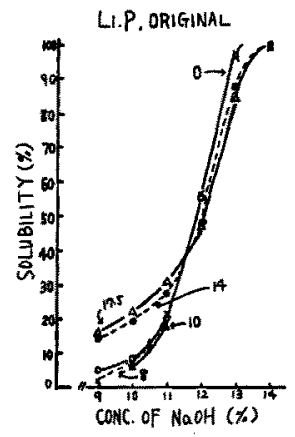

Fig. 5 Emulsion xanthation solubility curves of $\mathrm{Li} . \mathrm{P}$, steeped in different concentration of $\mathrm{NaOH}$ solutions

(Figures on each curve show the concentrations of steeping $\mathrm{NaOH}$ solutions)

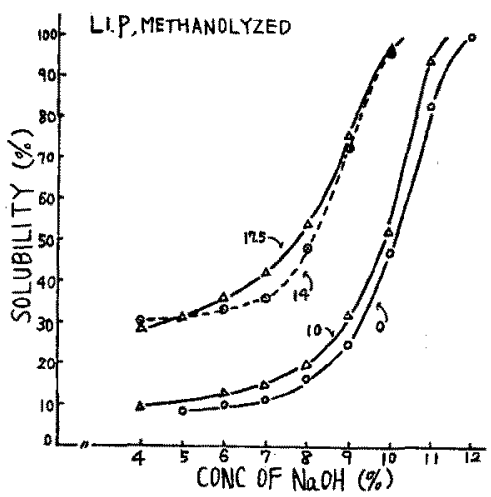

Fig. 6 Emulsion xanthation solubility curves of Li. P methanolyzed after steeping in different concentrations of $\mathrm{NaOH}$ solution (Figures on each curves show the concentrations of $\mathrm{NaOH}$ solutions)

とにした。

\section{IV. 考察}

\section{1. 曲線の婊示法}

$\mathrm{M}-\mathrm{W}$ 曲線はその位置と型によつて特性つけ西ことが

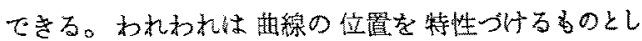
て，パルブの $50 \%$ が溶解するような $\mathrm{NaOH}$ 濃度を採 り，原ヘルプK対しては $[\bar{C}]_{0} ， \mathrm{M}$ 一試料に﨎しては

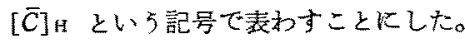

曲線の型については，富分子物の重合度分布を表琾す るために，重合度分布が指数変換正規分布をすると做定 し，变換函数和上び正規分布函数から无られる4コの心 ラメーターで示主方法りを応用した。この方法の原理は つぎ通りである。

正規分布函数を $\phi_{(x)} \equiv\left[x_{50}, \sigma\right]$ で表わすとき， 
$A C^{n}(C: \mathrm{NaOH}$ 濃度) なる指数変換を行 5 と, $\mathrm{M}-\mathrm{W}$ 曲楾は $x$ に関する正規分布で表示できると仮定する。 $x_{50}=C_{50}$ とすると，x とCの間には両対数方腿䋸上て (1) 式が成立する。

$$
\log \frac{C^{50}}{C-i} \mid \log \frac{C+i}{C_{50}}=\gamma=\log \frac{x_{50}}{x-i} \log \frac{x+i}{x_{50}}
$$

また確立方眼秖上の直線 $x=\alpha \xi$ を両対数方眼柢上に 移すと, $\log x=\log \alpha+\log \xi$ となり, $\log x$ と $\log \xi の$ 関係は $\log x$ 軸上に $45^{\circ}$ の直線となる。従つて (2) 式 が成立しなくてはならない。

$$
\log \frac{x_{50}}{x-i} \log \frac{x+i}{x_{50}}=\gamma=\log \frac{\xi_{50}}{\xi-i} \log \frac{\xi+i}{\xi_{50}}
$$

$\gamma$ は㬰験データーからえられるので， $\xi_{50}$ の原点をど こに巽ぶかという問題が残る。竹中は(2) 式の後半の原 点として種々の值を選んで計算し，士iに対応するそれ それの曲線をつくり，与克られた $\gamma$ 飞対応する $\xi_{50}$ を 曲線上から求め，これから図式解法て $A ， n ， \sigma$ を求め ている。本法をそのままわれわれのデーターに適用した ところ，実测偖と計算值がきすめてよく一致する場合と 多少一致しない場合とがあつた。一例を Fig. 7 の曲線 a に示す。えられたパラメーターのうち，C $C_{50}$ はパルプの

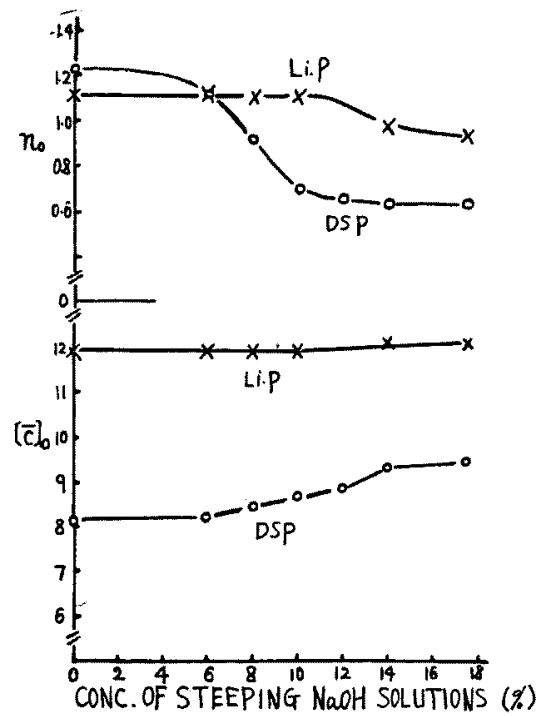

Fig. 8 Relation between characteristics of emulsion xanthation solubility curves $\left(n_{0}\right.$ $\left.\&[\bar{C}]_{0}\right)$ and concentrations of steeping $\mathrm{NaOH}$ solutions

$$
\begin{aligned}
& 0-\text { :OBSERVED } \\
& x \ldots \text { :CALCULATED }
\end{aligned}
$$

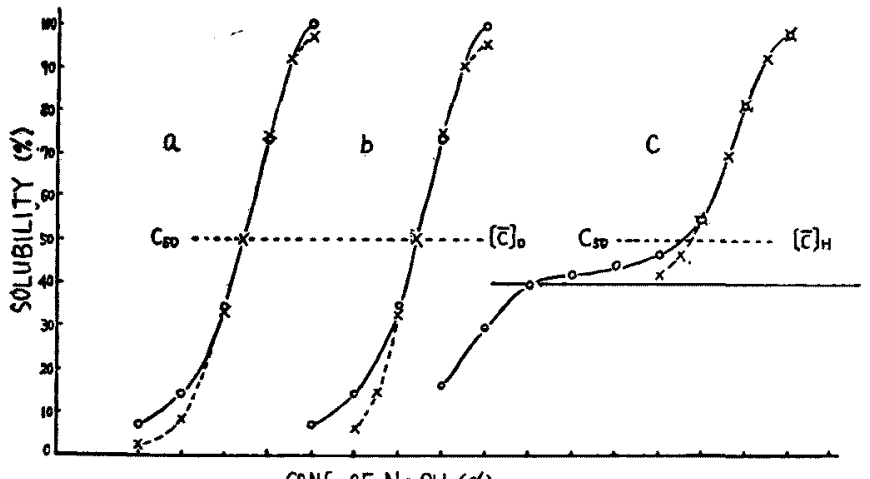

CONC OF $\mathrm{NaOH}(\%)$

Fig. 7 Comparison between observed curve and calculated curve. $n=2.70, C_{50}=9.40$ となる。この場 合，両者の $\sigma$ および $n$ がそれぞれ異 なつた数篧を与えるため，闭者の亘接 の比較は困難でする。方九的れは。 を一定としたときの $n$ をもつて，而 楾の型の特性值として用いた。一定の

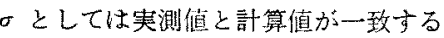
ぐあいから，適当と思われた $\sigma=1.48$ を選んだ。

このようにのを一定にすると， $n$ の增加は曲楾の傾斜が急にな苟傾问を 示すここの方法に上る計算推が実政储 か力春馳する程度は Fig. 7 の曲線 b の通りである。な扣，この例のように 計算俁が実娩檤に完全に一致しないと

50\% が溶解するようになる $\mathrm{NaOH}$ 濃度で，曲線の位置 の表示として前に選んた $[\bar{C}]_{0},[\bar{C}]_{1}$ に当る。 $n$ は曲線 の非対称性を示し，低 $\mathrm{NaOH}$ 濃度側に裾を引いている 場合は $n>1$, 近の場合は $n<1$, 対称なら $n=1$ であ る。1よりの距りはその壁度を示す。のは正規分布变換 後に拈ける分布のひろがりを示す。 $A$ は $x_{50}=C_{50}$ と括 いたため数学上必要なパラメーターで，物理的あるいは 化学的意味を持たない。

このようにして求めた例を挙げると，末処理 DSP： $\sigma$ $=2.0, n=0.95, C_{50}=8.10$, 未処理 DKP : $\sigma=0.60$,
きはなるハく溶解量の多いところで一致するよ5に $n$ を選んだ。原パルプについてえられた $n$ を利とする。 またアルカリ浸婊パルプの M-試料についてえられる $\mathrm{M}$ -W 曲線は，しばしば一つの指数变换正規分布画数で表

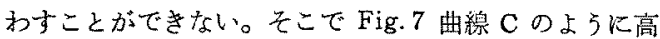
L. O. 部犬゙けについて $n$ を求め，これを 拓低 $\mathrm{NaOH}$ 濃度域に和けるやや水平に近い部分を低 $\mathrm{L}$.

0. 部として都らことにした。

このようにしてえられた $[\bar{C}]_{0} ， n_{0}$ を用いて，浸漬ア ルカリ濃度の変化に伴5 $\mathrm{M}-\mathrm{W}$ 曲湶の変化を图示する 
と Fig.8 のようになる。浸清 $\mathrm{NaOH}$ 濃度が增加するに つれて, 原ハルプの $\mathrm{M}-\mathrm{W}$ 曲線の位置 $[\bar{C}]_{0}$ は Li.Pでは 変方らないが, DSP では明らか火高 $\mathrm{NaOH}$ 漶度側に移 ること（[C] $]_{0}$ の增加）を示している。曲線の僧斜 $n_{0}$ K ついてみると，Li. P, DSP 其红浸溃 $\mathrm{NaOH}$ 濃度が增加す るにつれて, 曲線の䝨斜は緩やがなるが ( $n_{0}$ の减少)， その傾向はDSP 飞执いて大きい。以上の事実からここ に選ば机たパラメーター $n_{0},[\bar{C}]_{0}$ は, 曲線の変化 (Fig, 3 抢よび5)をよく表現しているとい兄る。

\section{2. 微細構造の特性值}

以上の上5に原パルプの $\mathrm{M}-\mathrm{W}$ 曲線のパラメーターが えられたので，つぎ $\mathrm{M}$-試料の $\mathrm{M}-\mathrm{W}$ 曲線の変化，す なわらアルカリ浸漬による微紐構蕧の变化を特性づける パラメーターを定好る。

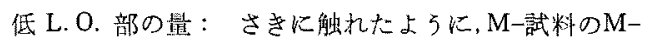
W曲綜飞みられるきや水平に近い部分を低L. O. 部と見

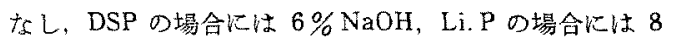
$\% \mathrm{NaOH}$ に括外る E.X. 溶解量をるつて低 L. O. 部の 量とした。

$[\bar{C}] ： こ れ は \mathrm{M}$-試料の $50 \%$ が E.X. によつて溶解 するの纪必要な $\mathrm{NaOH}$ 瀑度であって, 同時に L.O. の高

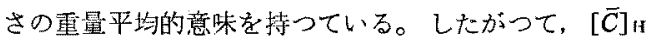
をＬ.O.の平均の高さとい5意味で一つのパラメーター として選えだ。

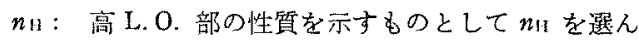
た。 $n$ 世 は高 L. O. 部の曲線の傾斜, すなわちオーダー 分布状態を示す尺度と考光ることができる。

\section{3. 各パラメーターによる考察}

原パルプの溶解性の目安としては，no, $[\bar{C}]_{0}$ 以外に未， 処理 DSP, Li.P がそれぞれはは 100\% 溶解するよ5に なる $\mathrm{NaOH}$ 滥度比沶ける E.X. 残渣量を採つた。すな わち DSP ては $10 \% \mathrm{NaOH}$, Li.P で $13 \% \mathrm{NaOH}$ 亿 特けるE.X. 残渣量を採つた。さらに Li.P の場合には アルカリ浸漬浱度が一定濃度以上になると, $11 \%$ 以下 の $\mathrm{NaOH}$ 淟度に嗮ける E.X. 溶解性が增加するので， これに対して 10\% NaOH-E.X. の可溶度を選んた。

低 L.O. 量と no 招上び溶解性の関係：さき定め た低 L.O. 量之曲缐の傾斜 $\left(n_{0}\right)$ 打よび溶僻性の目安を プロットすると、Fig. 9 がえらられる。Fig. 9 a か⿰ 低 L.O. 量が增加するにつれて，パルプの溶解性が低下 することがわかる。この作用は DSP において影著であ る。Li.P の場合沉は, 溶解阻害と同時汇溶解促進の作

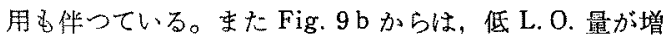
加する纪つれて $n_{0}$ が减少，すなわち $\mathrm{M}-\mathrm{W}$ 曲楾の候斜 が緩やが炕ることがわかる。この傾向は DSP の場合 飞著しい。

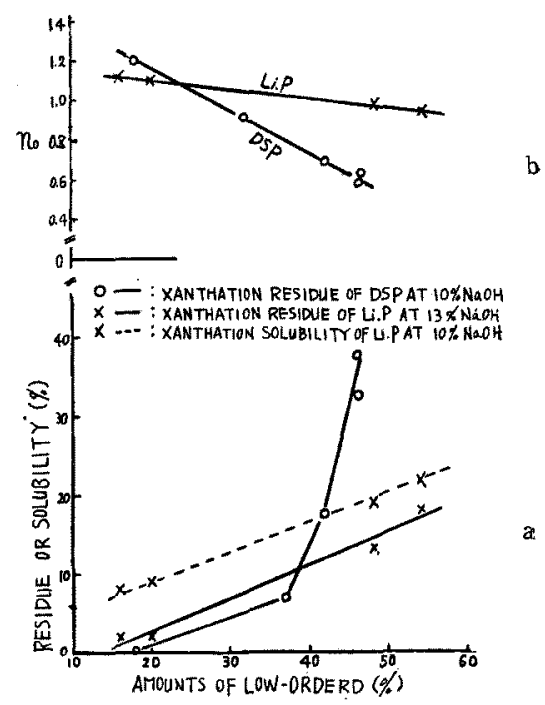

Fig. 9 Dependency of xanthation solubility and slope of solubility curve $\left(n_{0}\right)$ on amounts of low-ordered

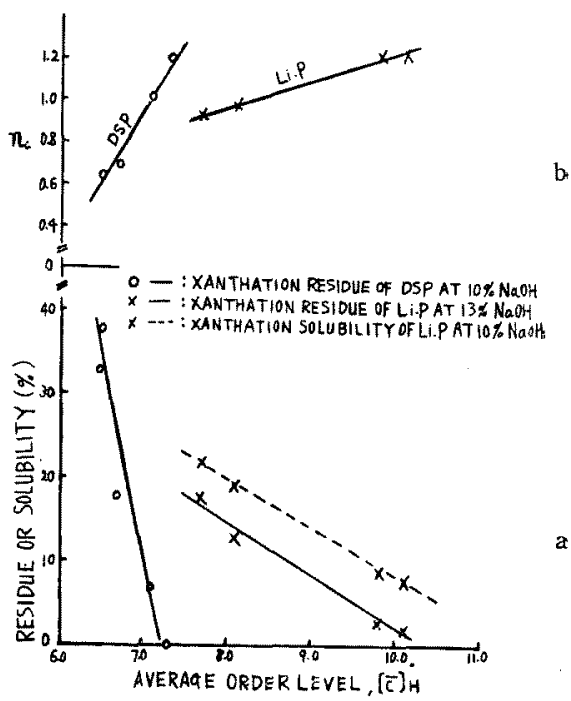

Fig. 10 Depenedency of xanthation solubility and slope of solubility curve $\left(\boldsymbol{n}_{0}\right)$ on average order level $[\overline{\mathrm{C}}]_{1}$

$[\bar{C}]_{\text {II }}$ と $n_{0}$ お上び溶解性の関倸： L.O. の平均の高 さ $[\bar{C}]$ ルと施よび溶解性の目安の関係をプロットす ると、Fig. 10 が党られる。

この図から，L．．平均の高さが低くなるにつれて， $n_{0}$ および溶解性は城少することがわかる。ただし Li.P の場合は同時飞 $10 \% \mathrm{NaOH}-\mathrm{E} . \mathrm{X}$. 飞和㚈方溶解性法向 上し，低 L.O. 量と not拉よび溶解性の関係 (Fig.9) と 
同じ傾向にあることがわかる。しかもすべての関倸にお いて，ほ活直線関係にある。

$n$ 上 $n_{0}$ の関係：前 2 項から $n_{0}$ 和よび溶解性は低 L. O. 量および平均の L. O. 高さと密接な関係にあるこ とがかからたが, Fig.11 からは高 L. O. 部の性質 $\left(n_{\mathrm{H}}\right)$ も版に反映していることがわかる。

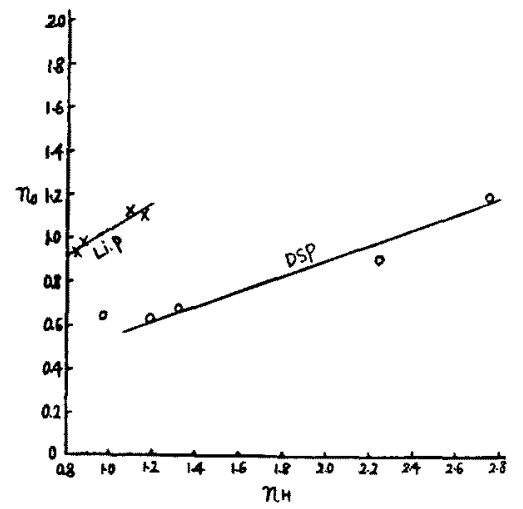

Fig. 11 Relation between slope of solubility curve $\left(n_{0}\right)$ and characteristic of highordered $\left(n_{H}\right)$

いかゆる L.O. 分布と $n_{0}$ の関係： 前記の通り曲線 の傾斜 $n_{0}$ 注高 L. O. および低 L. O. 部, すなわ方全体 のL.O. 分布に関係していることが5かが古る。 M-試 料の M-W 曲線 (Fig. 4 占よび6) からいかゆ L. O. 分布曲線を求め, 右山 (高L.O. 部) と左山 (低L.O. 部) の高さに対し 利をプロットすると，Fig. 12 がえられ 万。

DSP の場合, 右山おょび左山の位置は浸漬アルカリ浱 度が变つてもほとんど移動しないのて，ピークの高さは

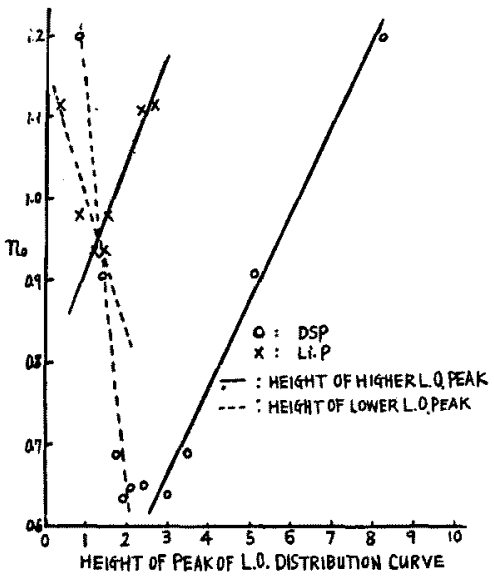

Fig. 12 Relation between slope of solubility curve and lateral order distribution
分布の均一性の尺度となる。したがつて Fig. 12 は右山 の均一性が高いほど，また左山のビークが低いほど $n_{0}$ は大となり, 原パルプの $\mathrm{M}-\mathrm{W}$ 曲線の傾斜が急になるこ とを示している。なお左山が低いことは低 L.O. 量が少 ないと解してよい。

この傾问は Li.P についても同様であつて，noは L. O. 分布状態をきわめてよく反映しているといえる。Li.P

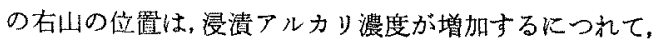
明瞭に低いオーダーのほ5に移る。しかもFig.12のよ 5にDSP と同様の関係を与えることは，Li.P の右山の 位置は $n_{0}$ に関倸が無く，均一性だけが $n_{0}$ に影響してい ることになる。これは，L.O. のある高さ以上ではすへ て高 L. O. 部として働き，そのオーダーの範围では，才 ーダーの高さよりか不均一性が $\mathrm{M}-\mathrm{W}$ 曲線汇影響するた めであると考えられる。

曲線の位置 $[\bar{C}]_{0} ： M-W$ 曲線の佰斜 $n_{0}$ に閐しては, 本実験範围の全般にわたつて，いわゆるL．．，分布の不 均一性と直線的関保にあることが見出された。しかしな がら曲線の位置 $[\bar{C}]_{0}$ に関しては，(1) 未処理ハルプの 場合はいずれる $[\bar{C}]_{H}$ が高くなるにつれて $[\bar{C}]_{0}$ も高く

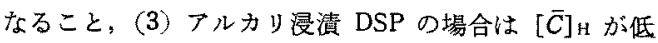

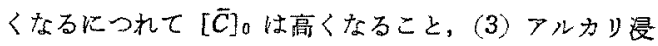

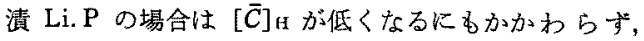
$[\bar{C}]_{0}$ はばは一定であるという結果が充られた。このう ち(1) の埸合は, L. O. の平均の高さが艺のパルプの M 一W 曲楾の位置に值接反映している。つぎに(2)和よび (3) の場合について考察する。

パルブの E.X. 溶解性と $[\bar{C}]$ のの関係をプロットする と, Fig. 13 がえられる。DSP の場合は溶解性が低下す

\section{DSP: XANTHATION RESIDUE AT IOZNAOH} LIP: XANTHATION RESIDUE AT I3\% NaOH

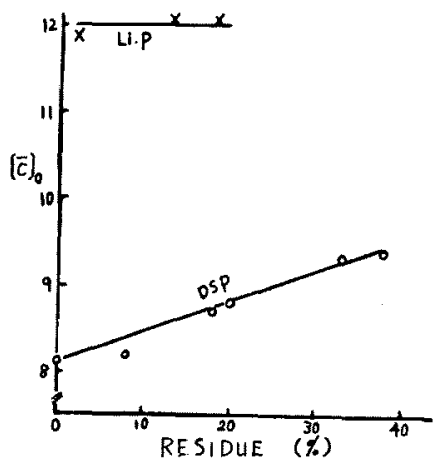

Fig. 13 Relation between $\mathrm{NaOH}$ concentratoin. at which half of the material dissolves and xanthation residue at constant concentration of $\mathrm{NaOH}$ solution in emulsion xanthation 
るにつれて，M-W曲線の位置 $[C]$ 。は增加している。

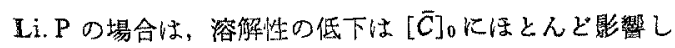
ていない。

DSP は全 $\mathrm{NaOH}$ 濃度域 (6〜12\%) にわたつて, 溶解 性が低下しているから (Fig. 3)，Fig. 13 の上うな直線 関倸が党られるのであるう。Li.P の場合仕高 $\mathrm{NaOH}$ 浱 度 (11.5 14\%) 飞括计る溶解性の低下が少い上下, 11 \%以下の $\mathrm{NaOH}$ 濃度域に括ける溶解性の增加があるた

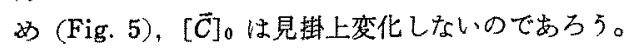

$[\bar{C}]_{0}$ に関する DSP とLi.P の举動の羔巽は, 重合度 分布拉よび形熊的構造因子の差飞基つくものとも考之ら れるが，徽細满造の立場からはつぎのよ5に考えること ができる。

DSP の溶解性は低 L. O. 量の增加と共に，むた L.O. の平均の高さの低下と共に，低下した（Fig. 9 および 10)。これは E.X.の上万な反応系では, 易膨潤性であ る低 L. O. 量がが增加すると, 硫化反応が急速にこの部 分に起つて局部的過度膨潤を生し，全体の溶解性を低下 させるものと考えられるり。浸漬アルカリ濃度が增加寸 るにつれて，低 L. O. 量も增加するが同時にアクセシビ リテイーも增加し，不均一硫化の傾向をますます高める であろら。アクセシビリティーとして水分吸着量を採 ク、これと低 L.O. 量との関係を求めると Fig. 14 a が 元られる。水分吸着量林低 L. O. 量の增加と共淔線的 飞增加している。しかるDSP と Li.Pでは去の直線の傾 斜は添ぼ同じで岕る。しかるに水分吸着量と $n_{0}$ との関 係(Fig. 14 b) では，Li.P特よび DSP 共に直線関倸 与えて, M-W 曲湶の傾斜がアクセシビリティーの增加 につれて減少することを示すが，Li.P では直線の傾斜 が小さく、アアクセシビリティー增大比】る溶解阻害作用 の程度が少ないことを物語つている。これは水分吸着量 と L.O.の平均の高さを示したFig. 15 の結果からみて， Li.Pの L.O. が高いためと思かれる。この図は同一丁 タセシピリティー(水分吸着量)に打る Li.PのL.O. はつ补 DSP のL.O.より高いことを示している。さら にマーセル化 Li.P の水分吸着量は $14 \%$ 、このときの $[\bar{C}]_{\text {н }}$ は 7.70 であるが，こ机は未処理 DSP の $[\bar{C}]_{H}:$ 7.30 上りな和高い。このために L.O.の低下に伴うフ クセシビリティーの增大は一部は溶解促進作用として現 われ，一方溶解阻害作用も少なくなるものと思われる。

したがつて M-W 曲線の位䈯 $[\bar{C}]_{0}$ は, 平均の L.O. の高さ以外飞も L.O. の高さとアクセシビリティーの相

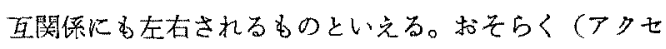
シビリティーク/(L.O.の高さ) が一定の割合の範团で， 未処理 DSP，DKP 打よび Li.P間炕みられた関係，す なわち $[\widetilde{C}]_{n}$ の小なるものはど $[\bar{C}]_{0}$ る小であるとい

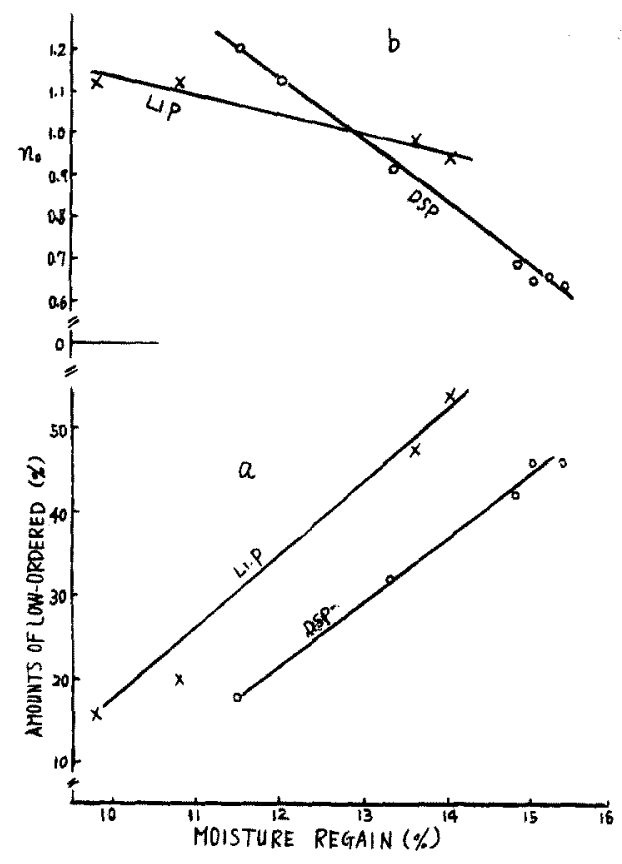

Fig. 14 Relation between moisture regain and amounts of low-ordered or slope of solubility curves $\left(n_{0}\right)$

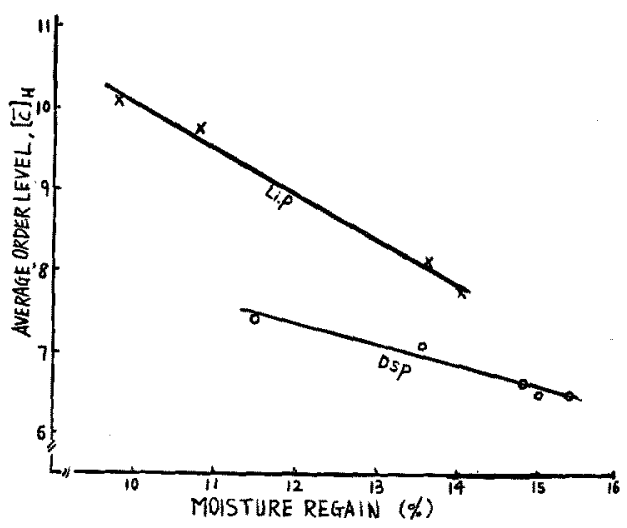

Fig. 15 Relation between moisture regain and average order level $[\bar{C}]_{H:}$

關係が成立するものであらう。

一般にセルロース絨維の比表面積の增大は反応性を高 めるが、膨潤溶解を伴了場合, とくにE.X.の上らな卜 ポケミカルな反応で溶解が円滑に進むためには，此表面 稳と L.O.の高さの間に適当なバランスが必要である。

\section{V. 総括}

パルプの微稩構造が $M-W$ 曲楾にお上ほす影響を検討 
し、つぎの結果をえた。

1. いわゆる L. O. 分布の不均一なるのほど，また低

L.0. 量が多いはど，M-W 曲線の傾斜は小となる。

2. 平均の L. O. の高さの低いるのど，そのパルブ の $\mathrm{M}-\mathrm{W}$ 曲楾の位置る低く（低 $\mathrm{NaOH}$ 漂度側）なる傾 向にあるが，平均のL.O. の高さだけに支配されるもの ではない。L.O. 分布状態とくに比表面積と L.O. の高 さの相互関係によつて决る。

\section{文献}

1) R. Bartunek ; Cellulose Chemie., 22, 56 (1944)

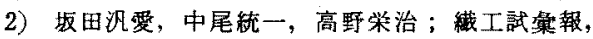
No. 28 (1954)
3) 万木正；工化, 58, 27 (1955) 前田弘邦；峨学誌, 12,6 (1956)

4) Y.Tsuda \& S.Mukoyama; Bull. Chem. Soc. Japan., 30, 271 (1957)

5) O. Samuelson, R. H. Anderson \& F. Gärtner ; Tappi, 37, 236 (1954)

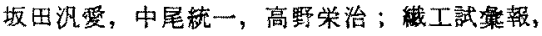
No. 33 (1955)

6) 竹中治夫；日化， 73，544(1952)

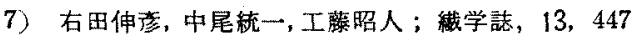
(1957)

\section{報文投稿者への衔注意}

（1）本学会誌に報文を投稿する場合は必ず本学会所定の原稿用科をお使い下さい。括申越により実費（100枚 つづり 1 冊送料とも100円)でお頒ちします。

（2）報文には必ず内容のわかる程度の英文抄録（約 200 語）およびその和文をつけて下さい。文字はなるぺく タイプライタで1行おきに書いて下さい。手で書く場合はブャックレターで1行辞に書くこと。

（3）報文に添付する図面は白紙（淡青色の方眼紙に限り差支えない）にていねいに濃くすみ書きして下さい。

图面の大きさはなるべく左右 6 緾または 12 跬に樎尺できるよ 5にこの倍位（左右 12 粴また は24糧）に線の太さおよび文 字の大きさを考えて書いて下さ い。細い線で書いた小さな図面 に太い大きな文字，または太い 線で書いた大きい図面に細い小 さい文字は樎尺できませんから 十分御过意下さい。

図面の畫き方は右記の例に従 つて下さい。(字体に注意)なお 小さい図面は約失の拓それがあ りますから原稿用紙の裏側に貼 付けて下さい。
因面の鲁き方の兒本

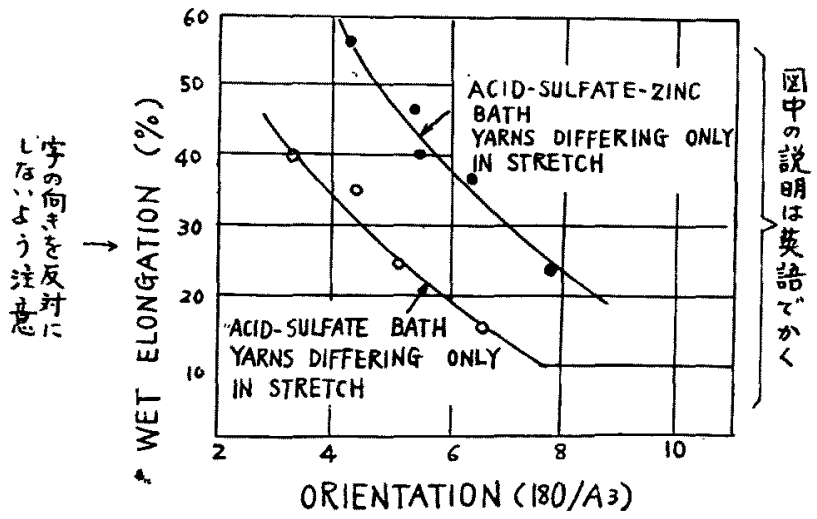

$\therefore \underbrace{2}$ 活 Fig. 7. Orientation-elongation relationships (wet) for experimental rayons [3i] 